\title{
Fish and Fishing in the Roman World
}

\author{
Annalisa Marzano ${ }^{1}$ (D) \\ Published online: 5 July 2018 \\ (c) The Author(s) 2018
}

\begin{abstract}
This article focuses on two aspects related to fish and fishing. It first discusses the social context for the consumption of preserved and fresh fish, showing that generally consumption of certain types of fresh fish conferred status, whereas consumption of preserved fish, being more affordable, was attested across social strata. The article then moves on to examine the organisation of the 'fishing industry', specifically the relationship between fish-salting establishments and the fishermen who provided the fish. Although we have many literary, documentary, and archaeological sources for fish preservation and fishing techniques in classical antiquity, the fishermen engaged in large-scale fishing remain rather elusive.
\end{abstract}

Keywords Fish consumption $\cdot$ Fish salting $\cdot$ Fishermen $\cdot$ Business organisation $\cdot$ Societates

An abundant scholarly literature focusing on the production and commercialisation of salted fish products in classical antiquity exists, for which we have ample archaeological evidence in the remains of fish-salting establishments and the amphorae used to commercialise the products. ${ }^{1}$ Within this literature, it is only more recently that scholars' attention has shifted to include also the study of ancient fishing techniques and fishing gear. ${ }^{2}$ In regard to the role of fish in the ancient diet-whether fresh or preserved-research has focused, on the one hand, on the specific socio-cultural context of fish-consumption, and on the other, on the use of scientific techniques such as isotope analysis to determine what role marine protein had in people's diet (e.g., Purcell 1995; Craig et al. 2009).

\footnotetext{
1 There is a vast bibliography on this subject; in addition to the bibliographical references to the contributions in this volume and to those in García Vargas (2016), see bibliography at http://oxrep.classics.ox.ac. uk/bibliographies/fish_industries_garum_production_bibliography/ (up to 2007) (accessed January 2018).

2 E.g., see contributions in Bekker-Nielsen and Bernal Casasola (2010). For discussion and further bibliographical references see Marzano (2013, 51-79).
}

Annalisa Marzano

a.marzano@reading.ac.uk

1 University of Reading, Reading, UK 
This paper focuses on two aspects related to fish and fishing: (a) the social context for the consumption of preserved and fresh fish; and, (b) the organisation of the 'fishing industry' in connection with fish-salting installations, particularly the relationship between the fish-salting activity and the fishermen who provided the fish. ${ }^{3}$ My discussion focuses first and foremost on the written documentation, both literary and documentary; reference to key archaeological data will be made as and when necessary, but it is beyond the scope of this article to offer a systematic survey of the archaeological and zooarchaeological evidence for fish consumption and fishing activity.

\section{Tell Me What Fish You Eat ...}

A fundamental difference between the consumption of preserved and fresh fish in the Roman world is that while the former was part of the diet of a large part of the population, the latter, by and large, was the reserve of the wealthier strata of society. ${ }^{4}$ As discussed below, this dichotomy was not universal, and there were other elements defining the relationship between fresh and preserved fish, as for instance the different culinary role fresh and preserved fish could have. In a meal consisting of more than one dish, preserved fish was mainly consumed as appetiser, while fresh fish could be either the main dish or, especially for small types of fish, also feature among the appetisers; fish sauces, being condiments, featured in most culinary preparations (Mylona 2008, 110).

Unlike most salted or dried fish, fresh fish could have 'social value', conferring status to those who consumed it or gave it as a gift in order to impress others. This, however, did not apply to every kind of fresh fish; there were types that were sought after and would fetch high prices at the market, and others that a wider spectrum of the population could afford. There was not one general rule when it came to the consumption and desirability of fresh fish, as obviously geographic location was a determining factor: those who lived in coastal areas had easier access to fresh fish and seafood. The investigations carried out at the coastal town of Herculaneum in the cardo $\mathrm{V}$ sewer have shown how rich in seafood the diet of those who lived in that street was (Rowan 2014; Nicholson et al. this volume). Since the buildings along that street were a combination of commercial and different types of residential premises, comprising also non-elite dwellings, the Herculaneum sewer data indicate consumption of fresh seafood across social strata. Coastal location would have meant a higher availability of fresh fish, and this was probably true particularly in the case of port towns. From Roman Corinth comes the example of a Roman butcher's shop excavated near the theatre. The establishment also sold cooked food, including, it seems, fish and presumably the clientele included ordinary people (Mylona 2008, 38-43 and Table 5.1c).

Furthermore, culinary fashions could change over time: what might have been a 'luxury food' in a particular region or particular time, might have instead been a more common fare in other areas or ages (Van der Veen 2003). An oft-quoted example of the changing fashion in sea-food desirability regards the sturgeon, a non-Mediterranean fish prized because of

\footnotetext{
3 Discussion of large-scale fishing in general and the relationship between fishermen (fishing for fish to be sold fresh) and fishmongers which emerges from various epigraphic texts cannot be properly addressed in this venue and will be referred to only incidentally; on these issues the reader is invited to consult Marzano (2013).

4 The type and size of fresh fish, as well as geographic location and culinary fashion were all factors affecting the social accessibility of fresh fish.
} 
its rarity: whereas in the Republican period it was a fish with high social value, it seems to have then gone out of fashion for some time, to then re-gain popularity as 'a fish worthy of an emperor'. 5

As a rule of thumb, we can say that large specimens of certain types of fresh fish (e.g., mullet, bass, bream, gilthead) had a higher commercial, and hence social value, than fry and smaller specimens; that marine fish was, generally, more sought after than freshwater fish; and that, in terms of status and monetary value, fresh fish was superior to preserved fish. Within each of these categories, however, a hierarchy of desirability was in place. Since literary sources focus primarily on the wealthy, they give much information on the fish and seafood served at the lavish banquets of the elite. ${ }^{6}$ In these contexts, fish and seafood often mark, together with other special foods such as peacocks or flamingos, the extravagance and level of expenditure of the rich. Attempts at curbing culinary displays comprising seafood are attested relatively early in Rome's history: one of the Republican sumptuary laws, the Lex Aemilia, probably dated to $115 \mathrm{BC}$, forbid molluscs, exotic birds, and dormice being served at banquets. ${ }^{7}$

In the imperial period, the social value of fish and seafood is something often referred to in satires. Martial writes of the different types of food served at a banquet to stress the very different social standing of the host and client-guest: whereas the former is served a turbot and oysters, the socially-inferior guest has to dine on cheaper molluscs and a brill. ${ }^{8}$ In another epigram, the poet ridicules the social climber Papylus, who tried to impress people by sending as gifts fresh mullets and oysters, while he himself dined at home in great simplicity. ${ }^{9}$ Similarly, it is fresh fish (and one artaba of olives) that is chosen by the military veteran Tiberius Bellenus Gemellus as gift for one Egyptian official whose favours he wanted to gain. ${ }^{10}$ Thus, those who wanted to impress someone or recognise the higher ranking of an individual often chose to send specimens (preferably large) of fresh fish as gifts. ${ }^{11}$

The availability or scarcity of certain types of fish, culinary fashion, and specific sociocultural traditions, all contributed to determining the market price of the various kinds of fish, and the price in turn would further determine the 'social value' of each type of fish and its degree of desirability. The fragmentary and anecdotal nature of available evidence makes it difficult to address the question of the price of fish, but the type and size of the fish was important. Small species, such as sprats and sardines, were not considered of great quality. Sought after fish that could command high prices were large specimens of bass, sea bream, mullet, and gilthead. Such distinctions apply to the Classical world in general. Classical Greek authors regard anchovies and similar fish as something affordable by people of modest means, as exemplified by a fragment of a comedy by Timocles: the character Epichairekakos, while shopping for fish, asks the prices for eels, tuna, crayfish, and ray; but having just 4 bronze coins, can only afford sprats. ${ }^{12}$

\footnotetext{
5 Cfr. e.g., Plaut. Apud Macrob. 3.16.5-7; Lucilius apud Cic., de Fin. 2.24; Cic., de Fin. 2.91; Tusc. Disp. 3.43. Arcipenser as out of fashion: Plin., HN 9.60; desirable fish: Mart., Xenia 13.91.

${ }^{6}$ For a discussion of fish and fishing in Latin literature, up to the Augustan age, see Peurière (2003).

7 Plin., $H N$ 8.57.223.

8 Mart. 3.60.

9 Mart. 7.78.

10 P.Fay. 117, a letter dated to January AD 108, see Marzano (2013, 279-280).

11 See Purcell (1995); Marzano (2013, 273; 279-281) and two famous literary examples: Juvenal's Satire 4 (the extremely large turbot caught by a fisherman is sent to the emperor as a gift) and the anecdote in Suetornius, Tib. 60 (a fisherman presents himself to the emperor with a large mullet as a gift).

12 Passage discussed in Davidson $(1997,7)$.
} 
The well-known Hellenistic inscription from Akraiphia, near Lake Copais, gives a list of prices for various kinds of fish, marine and freshwater. ${ }^{13}$ In this list, most small-sized fish is cheaper than larger one, even within the same species. ${ }^{14}$ Charging higher prices for large fish of the same species is consistent with the anecdotes about the auction of fish in Rome in the early imperial period. They all concern particularly large specimens of red mullet, as in the case of three large red mullets sold for 30,000 sesterces. ${ }^{15}$

An imperial letter from Pergamum, probably Hadrianic in date, confirms that smallsized fish were affordable by common people. ${ }^{16}$ The letter addressed the wrongdoings of the money exchangers, such as imposing a surcharge for worn out coins, which seems to have affected the fishmongers in particular (Lytle 2010). The inscription reveals that common people bought 'small fish' and that they pooled together to make the purchase in denarii instead of the local bronze denominations. One denarius of these not better-identified small fish, however, was enough to be divided among several individuals. Furthermore, the text also shows that the local authority intervened in regulating the price of small fish only, possibly to control the price of fish that people with limited means could hope to buy (Lytle 2010, 288-289; Marzano 2013, 282).

A first-century AD expenditure account from Tebtynis in Roman Egypt, which registers the price for an otherwise unidentified black fish from the Nile, the korakinos, offers further clues about fish prices. ${ }^{17}$ The price for this fish varied between 1 and 2 obols per fish. The same document gives as 2 obols the price of two bread loaves or six eggs, showing that fresh, small-size fish was within the economic means of ordinary people.

A distinction between the price of marine and freshwater fish occurs in Diocletian's Price Edict of AD 301, although the limitations of such a source in the light of the variability of regional (and seasonal) prices for something such as fish ought to be remembered. The edict makes a distinction between marine and freshwater fish, and between first and second quality fish: 1 Italic pound ( $327.45 \mathrm{~g}$ ) of marine fish 'from rocky bottoms' is priced at 24 denarii (the same price as that for 24 eggs), while $1 \mathrm{lb}$ of 'second-quality marine fish', costs 16 denarii. Freshwater fish is cheaper: 12 denarii for $1 \mathrm{lb}$ of first quality fish and 8 denarii for second-quality. Sardines are listed separately, with a price of 16 denarii/ pound (Marzano 2013, 290).

Preserved fish, however, was another matter. Notwithstanding a few exceptions, it differed from fresh fish in terms of price and status conferral. Preserved, particularly salted, fish products, comprised a wide range: filleted fish available at various degrees of saltiness (and hence with different 'shelf life'); fish sauces, of which the most famous is garum, used for seasoning and as condiments; fish pastes, which could also include in their recipe herbs and vegetables; as well as, as revealed by archaeology, hybrid salted products made by mixing together the meat of fish, molluscs, and small mammals. ${ }^{18}$

\footnotetext{
13 SEG 32.450. The inscription presents various lacunae, but the marine fish, listed alphabetically, include c. 65-70 names, whereas the list for freshwater species is much shorter, comprising at least 6 names.

14 Lytle (2010), with previous bibliography, for a revision of the reading of one face of the inscription.

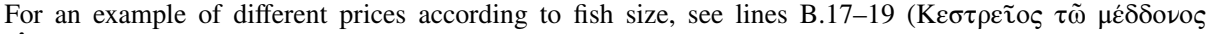

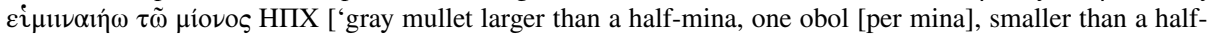
mina, 11 chalks [per mina]), and also lines B21-23.

15 Suet., Tib. 34.

16 IGR $4.352=$ OGIS 484 .

17 P. Mich. 2.123.

18 Curtis, (1991, esp. 6-15) for discussion of the various processed fish products; Marzano $(2013,121)$.
} 
Although there was a wide range of variation in the quality and the price of the preserved fish available on the market, with some high-quality products fetching high prices and featuring on the tables of the wealthy (e.g., the garum sociorum), ${ }^{19}$ salted fish products were, in general, within the reach of ordinary people. Because the fish was preserved, it could be traded to regions that were not in immediate proximity to the sea or rivers/lakes, thus featuring in the diet of a large section of the population. Documentary evidence from Roman Egypt indicated that salted fish featured as a staple food on the tables of all social classes, from ordinary people to the court of the emperor. ${ }^{20}$ There were specialised producers and sellers, but processed fish production in the domestic context was also common (Curtis 1991, 34-36). For the rest of the empire, it is more difficult to reconstruct the role of salted fish in the diet of ordinary individuals, since we lack the level of documentary evidence Egypt has to offer. Literary texts, by their nature, are skewed towards the elite, therefore we are limited to information provided by the distribution of amphorae used for salted products and the context in which they were recovered to provide some indication about the social context of their consumption. ${ }^{21}$ It is revealing that most rural villa sites in Italy, even for the phases of occupation where signs of decline are evident, offer evidence of Spanish or North African amphorae used for preserved fish and fish sauces. Also at a clearly non-elite rural site like Marzuolo in southern Tuscany, investigated by the 'Excavating the Roman Peasant Project', Baetican fish sauce was consumed (Vaccaro et al. 2017, 252-253). Salted fish and also the meat of marine mammals probably had a more significant role in the ancient diet than it has been recognised so far, as can be inferred from Galen's writings. In one passage he commented that dogfish were normally salted and consumed by ordinary people. Some paragraphs later, in summing up the salient information on 'cetaceans', comprising the dogfish, hammerhead sharks, large tuna, whale, dolphin, and seal, he says that 'all animals like these have flesh that is firm, unwholesome and full of residues' and that for this reason for the most part people first salt them. ${ }^{22}$ The earlier discussion of the flesh of one of the animals in this group, the dogfish, as being eaten salted by ordinary people suggests to me that also the salted flesh of Galen's other 'cetaceans', such as hammerhead sharks and dolphins, could feature in the diet of various social strata.

In Diocletian's Edict there is also mention of salted fish, which is priced at 6 denarii/ pound, thus considerably cheaper than the 16 denarii/pound for sardines and close to the price of the second quality fresh water fish (8 denarii/pound). If some fresh fish did not have a great taste owing to the environment in which they had lived and fed, salting could be seen as desirable, since it improved the taste. This is what Galen observes in the case of grey mullets, a fish that he says was commonly salted: the taste of the ones farmed in

\footnotetext{
19 According to Plin., HN 31.94, one congius (=3.375 1.) of garum sociorum cost 500 sesterces (a bit over half the annual salary of a legionary in the early first century AD). This garum attracted the attacks of moralists like Seneca: Ep. 95.

${ }^{20}$ P. Got. 3 mentions garum, salted, and fresh fish as provisions for the imperial table on occasion of Caracalla's visit to Alexandria in AD 215-216, see Curtis (1991, 134, n. 114).

21 Amphora evidence will necessarily reflect imports of goods produced elsewhere, since amphorae were the containers used in transmarine and fluvial shipments; consumption of preserved fish produced locally will not be reflected in amphora evidence and is more problematic to documents. In addition, re-use of amphorae makes the identification of the content problematic, even when using scientific techniques, since the polyunsaturated fish lipids are unstable chemically owing to oxidation. Lowe (2016) offers a synthetic overview of the trade in fish sauces from the W Mediterranean on the basis of amphora evidence. I do not address here the various studies using isotopic analysis for the reconstruction of the ancient diet.

22 Gal., On the Properties of Foodstuffs 3.30.728, 3.36.738=6.728, 6.738 Kühn.
} 
ponds improved greatly with salting. ${ }^{23}$ The salting of grey mullet is indeed attested archeologically, for instance from a Roman salting workshop in Seville: the great majority of the zooarchaeological finds consisted of grey mullet and sardines (Amores et al. 2007).

Preserved fish must have had a role in the diet of rural labourers too. Cato gives brief directions on how to make a good brine for home salting of meat or fish and a reference from Marcus Aurelius' correspondence to Fronto shows that, at least in the case of an imperial estate, small preserved sardines, boiled beans, and onions were the food eaten by the agricultural labourers. ${ }^{24}$ Salted fish featured also as food for ship crews: among the provisions recovered in the excavation of a shipwreck in the Rhône at Arles, sixty small vessels containing a fish paste made with sprat, anchovies, small mackerel and twaite shad were recovered. ${ }^{25}$ If we add to this the consumption of salted fish by the Roman army, which also stimulated the production of preserved fish sauces and pastes in northern Europe, complementing the shipments from Spain (Van Neer et al. 2010), it will be apparent that there was a vast demand for salted fish and associated products in the Roman world. In light of the great diffusion preserved fish products had, I now turn to the issue of who were the individuals at the core of such production; more specifically, can we say anything on the organisation of the fishing supplying the fish-salting establishments?

\section{Fishing and Fish Salting}

For the Roman period, the archaeological evidence for the production of preserved fish products (largely salted), ${ }^{26}$ and hence for commercial fishing, ${ }^{27}$ is abundant. Many Roman fish salting workshops-some large, some small—are known along the coasts of the Mediterranean and the Black Sea. However, when considering the written evidence the picture is much patchier, especially as far as the organisation of the fishing industry is concerned. While texts mention fish and salted fish products and literary works such as Oppian's and Aelian's inform us about fishing techniques, the fishermen involved remain elusive.

Fishing was a humble occupation, and fishermen as individuals were not of interest to the elite writers and their literary works. We do have didactic writings on fishing (e.g., Oppian's poem on fishing, dedicated to the emperor Marcus Aurelius) or depictions of fishing in mosaics of elegant houses and villas, but the reason these topics found an interested

23 On the Properties of Foodstuffs 3.24.713=6.713 Kühn.

${ }^{24}$ Cato, Agr. 88; Fronto, Ep. 4.6: conchim, caepas et maenas bene praegnatas, where, following Peurière (2003, 69), I take praegnatas to mean 'well-soaked'. We probably have here a reference to fish that had been both dried and salted to extend its shelf life.

25 Djaoui et al. (2014); these are Ostia II.401 vessels.

26 Archaeologically, it is fish salting that is well documented, since in the Roman era such operation took place in batteries of masonry vats. Drying (well attested in documentary evidence from e.g. Roman Egypt) and smoking must have been common too, but these activities are much more elusive archaeologically. For smoking installations from the Black Sea area see Højte (2005).

27 I do not consider here 'subsistence' fishing, that is small-scale fishing or occasional fishing on the part of farmers and the like to supplement their diet, but only large- and medium-scale fishing carried out by professional fishermen who sold their catch and it is these activities that I place under the label 'commercial fishing'. 
elite audience was because of a long philosophical tradition centred on the investigations of the nature of animals. ${ }^{28}$

So who were the men that supplied the fish-salting establishments with the fish to be processed? Were these fishermen the same individuals who made the various salted fish products? And how were the fishing and salting operations organised, or, in modern parlance, what was the business model adopted for these activities?

The available evidence juxtaposes western and eastern Mediterranean: in the west, abundant vestiges of fish-salting workshops exist, ${ }^{29}$ but epigraphic evidence pertaining to groups of fishermen that one may posit were working in large-scale fishing is scant. On the contrary, from the eastern Mediterranean come some (admittedly a handful) very interesting epigraphic documents attesting business partnerships for the purpose of commercial fishing, but there is much less evidence in terms of archaeological remains for fish-salting establishments. Undoubtedly, this is indicative of the changes to the landscape, for natural and anthropic causes that have destroyed ancient evidence, and of the different priorities of past archaeological investigations rather than reflecting the 'real' situation in antiquity (Mylona in this vol). The discovery, only relatively recently, of very large Roman fish-salting installations at Üçağız (ancient Teimiusa) in southern Turkey is a reminder of the effect of research priorities (Brandt and Kolb 2005, 101).

Among the corpus of surviving Latin inscriptions from the western Mediterranean, only nine texts refer to fishermen collectively (piscatores) ${ }^{30}$ Of these, five pertain to Ostia/Portus and mention the association of fishermen and divers of the Tiber, the association of boatmen and fishermen, and the fishermen and fishmongers. These inscriptions, because of the role the fishermen of Ostia/Portus played in the transport of goods up the Tiber including fiscal grain for the annona, for which they had in the later empire fiscal immunitas, and the recovery of lost cargos in the port, can hardly be taken as indicative of the 'fishing industry' at large (Sirks 1991, 268-285). Some fish-salting activity can be posited for the area of Portus and Ostia on the basis of the coastal lagoons that offered good fishing grounds, the presence of major salt works at the mouth of the Tiber, ${ }^{31}$ and the discovery on the Arles shipwreck mentioned above of jars of fish paste apparently originating from Ostia/Portus (Marzano 2017, 109). This, however, was not the typical case of archaeologically well-documented fish-salting establishments producing for a varied export market that we find in the Iberian Peninsula or in North Africa.

To these inscriptions, one can add the text mentioning a princeps piscator, which indirectly may suggest the existence of a group led by the commemorated individual, as well as a painted electoral advertisement from Pompeii naming 'piscicapi'. ${ }^{32}$ A late

\footnotetext{
28 These issues are addressed in Marzano (2013, 16-28); on the 'bountiful sea' motif in North African mosaics, see Ghedini and Novello (2005); Novello (2007, 37-38).

29 Bernal-Casasola (2016) offers an overview of the status of the studies on various aspects of salted fish production in antiquity and discussion of research agenda for future studies; Bernal authored many important publications on fish salting in Spain, in Pompeii, and on fishing gear, see bibliography in Bernal-Casasola (2016).

30 As inferred from the Clauss-Slaby databank (http://www.manfredclauss.de/gb/index.html, last accessed on 13 January, 2018): CIL 2.5929; 5.7850; 6.1872; 6.10229; 6.29700; 6.29702; 6.40638; 6.41382 (attesting caudicarii seu piscatores corporati); 14.409 (piscatorum propolarum).

31 Rome exploited these salt works at an early stage of her history: Liv. 1.33.9; Dion. Hal. 3.41.3. Cfr. also the Severan inscription ILS.6178, attesting the campus salinarum romanarum.

32 CIL VI.9799; CIL IV.826.
} 
second-century/early third-century inscription from Misenum names the propolae piscium, the fishmongers, which it has been suggested should in fact be understood as propolae et piscatores (Parma 1995). If one agrees with this reading, then this text too can be added to the very few attestations for groups of fishermen. The most striking aspect of this meagre epigraphic corpus is that, with the exception of a first-century AD inscription from Carthago Nova, a town known for the production of the famous garum sociorum, none comes from geographic areas well-known for the large-scale manufacture of preserved fish. Even the Carthago Nova inscription, however, does not offer clear evidence for fishermen supplying the fish-salting sector. It is a dedication to Caius Laetilius Apalus, the Lares, and Mercury by the piscatores et propolae, the fishermen and the fishmongers. Therefore, this collegium of fishermen probably refers to fishermen who were providing fresh fish for the urban market rather than fishermen working for the fish-salting sector. The combination of fishermen and fishmongers also occurs in a well-known Greek inscription from Julio-Claudian Ephesus, where the two groups, together, paid for the erection of the custom house for the tax on fish. ${ }^{33}$

On the whole, in the western Mediterranean attestations for organised groups of fishermen that can be clearly connected to the fish-salting industry are absent and this situation may indicate that, in the case of fish processing, those who fished and those who salted were the same individuals. Manilius' poem is often cited in this context, since he describes fishermen who, once their tuna catch had been landed on the beach, immediately proceed to clean and prepare the fish for salting. ${ }^{34}$

Extending the search for professional associations of fishermen to the eastern Mediterranean and Greek inscriptions, one can add a few more to the list (Marzano 2013, 40-48); they all come from areas that in antiquity had coastal lagoons or estuaries, hence areas with good fishing grounds. In two cases, Ephesus and Smyrna, it is also possible to see that associations grouped separately fishermen who specialised in a specific fishing technique, and hence who targeted specific fisheries. ${ }^{35}$

The most important epigraphic document containing information on the organisation of large-scale fishing is an inscription from Parion on the Marmara Sea (I. Parion 5), dated to either the first century or the second century AD. It attests to the rental of a fishing lookout, a business partnership comprising thirty-plus individuals, and the organisation of the fishing and distribution of tasks according to a specific hierarchy reminiscent of the organisation of, for example, Sicilian tuna fishing in modern times. The scale of the fishing operations attested by the document (a minimum of five boats with 5-7 men crew; the presence of an accountant and a financial controller), in addition to the fact that this group was probably mainly involved in fishing for horse mackerel (Trachurus trachurus) and tuna (Thunnidae) during their seasonal passage in the sea of Marmara, ${ }^{36}$ all point to fishing in connection with fish salting. Lytle's proposed integration of a lacuna in the text with ' $\tau \varepsilon[\mu \alpha \chi] \alpha[\rho \chi] \eta \sigma \alpha \nu \tau \varepsilon \varsigma^{\prime}$ (masters of the fish-salting operations) (Lytle 2006, 87), if correct, would indicate that the business partnership attested by this inscription was formed specifically for the joint purpose of fishing and fish salting. A partnership for the dual purpose of

\footnotetext{
33 I.Eph. Ia 20; Horsley (1989), Marzano (2013, 243). About 100 individuals are mentioned in the text, including wives and children. The custom house extracted payment of the customs dues on the fish landed at the harbour and brought for sale in the urban market.

34 Astron. 5.656-681.

35 SEG 48.1363; I. Smyrna 715.

36 Parion was renowned for these fishes: Ath. 3.88f, 3.92d; 3.116a-b; Plin., HN 32.146.
} 
fishing and salting, in this case in the context of fresh-water fishing, is also suggested in a second-century AD Egyptian papyrus. ${ }^{37}$ It is a fishing account and registers the value, in monetary terms, of the daily fish catches, but for some entries the term tarich(ia), salted fish, appears rather than the money value, thus highlighting the involvement of the fishermen in both fishing and salting.

All in all, when considering fishing for fish salting, the scant available evidence suggests that the same individuals fished and salted the fish and that the business partnership offered a suitable 'business model'. ${ }^{38}$ Whereas epigraphic evidence for groups of fishermen from the western Mediterranean pertains to collegia which appear to have mainly collaborated with the fishmongers selling fresh fish, in the context of fishing for fish salting it is business partnerships that are attested. The scale of the operations required by fishing for migratory pelagic fish meant that the equipment needed (e.g., several lengths of large seine nets; several boats) was beyond the means of any individual fisherman. Such situation finds parallels in later historical periods. In medieval France wealthy individuals, such as the bishop of Artaud, are attested financing fishermen by providing the boats and other needed equipment; in return the fishermen had to give a large portion of their catch, whereas in medieval Sicily three fine nets cost more than a tonne of fish (Bresc 1985, 1986). Centuries later, in southern Spain, we find again the elites involved in financing, and profiting from, the almadraba fisheries (García Vargas 2016). Business partnership, such as the Parium one discussed above, allowed individuals of different means to pool their resources together, acquiring the equipment, manpower, and know-how needed in large-scale fishing.

\section{Conclusions}

Fish occupied an ambiguous place in ancient cultural constructs about food. Some kinds of fish were expensive and sought after by the rich, others were seen as food for the common people, the result of the fact that, depending on the product, fish could be either available on a large scale, and consumed across all social strata, as in the case of most-but not allsalted fish and sauces, or be a rare and expensive commodity, as in the case of large specimens of specific kinds of fresh fish, such as the 2-kg red mullet sold in Rome for 5000 sesterces or the huge turbot that Juvenal imagines was sent as a gift to the emperor himself. ${ }^{39}$

On the whole, fishermen in antiquity had a low social status and although fishing could be the topic of literary works, of mosaics in elite dwellings, and a recreational activity, the ordinary men who engaged in large-scale fishing and supplied the many fish-salting establishments of the Roman world remain almost invisible. It seems very likely that the same individuals engaged both in fishing and salting the fish, but to date we do not have definite evidence. There are only few surviving attestations of groups of fishermen from the Roman Mediterranean. Some clearly refer to proper collegia, which seemed to have worked in collaboration with the fishmongers, who sold only fresh fish. Others were business partnerships (societates) formed in order to operate large-scale fishing, and, possibly, also fish-salting operations. Although the evidence is scant, it seems that, leaving aside

\footnotetext{
37 P.Oxy. 49.3495.

38 The limited scope of this paper prevents me from addressing the issue of the fish-salting operations attested in some maritime villas, for which servile manpower engaged in other task on the fundus outside the fishing season can be posited.

39 Sen., Ep. Mor. 9.42; Juv., Sat. 4.
} 
the case of fish-salting workshops attested in maritime villas, societates offered a suitable business model for running large-scale fishing and fish-salting operations: they helped in finding sufficient specialised manpower and the required capital for the fishing equipment, the lease of fishing lookouts, and the creation of the infrastructure needed for the salting operations. This is the model of production that has been proposed for major production centres such as Gades and for Carthago Nova's garum sociorum, whose label name derived from a societas possibly first established to exploit the salt works of the area and which subsequently also started the manufacture of salted fish products. ${ }^{40}$

I conclude by turning to a rather unlikely source, the so-called Colloquia of the Hermeneumata Pseudodositheana,$^{41}$ in which we find examples of desirable foods for a special day. One passage reads: 'since it is a feast day, they got us vegetables, good salt fish and fresh fish, meat, sweet wine, and chickens'. ${ }^{42}$ Note the specification that the salted fish had to be 'good'. On a feast day, not any kind of preserved fish would do, but fresh fish does not require such a qualifier: if it is fresh, it is worthy of the feast.

Open Access This article is distributed under the terms of the Creative Commons Attribution 4.0 International License (http://creativecommons.org/licenses/by/4.0/), which permits unrestricted use, distribution, and reproduction in any medium, provided you give appropriate credit to the original author(s) and the source, provide a link to the Creative Commons license, and indicate if changes were made.

\section{References}

Amores F et al. (2007) Una factoría altoimperial de salazones en Hispalis (Sevilla España). In: Lagóstena L, Bernal D, Arévalo A (eds) Congreso Internacional Cetariae 2005. Salsas y Salazones de pescado en occidente durante la antigüedad. Cadiz, 7-9 Noviembre 2005. BAR int. series 1686. J and E Hedges, Oxford, pp 335-339

Bekker-Nielsen T, Bernal Casasola D (eds) (2010) Ancient nets and fishing gear: proceedings of the international workshop on 'nets and fishing gear in classical antiquity: a first approach'. Cádiz, 5-17 Nov 2007. Universidad de Cádiz, Servicios de Publicaciones and Aarhus University Press, Cadiz and Aarhus

Bernal-Casasola D (2016) Garum in context: new times, same topics in the post-Ponsich era. In: BekkerNielsen T, Gertwagen R (eds) The inland seas: towards an ecohistory of the Mediterranean and the Black Sea. F. Steiner Verlag, Stuttgart, pp 187-214

Brandt H, Kolb F (2005) Lycia et Pamphylia: Eine römische Provinz im Südwesten Kleinasiens. Von Zabern, Mainz am Rhein

Bresc H (1985) Pêche et coraillage aux derniers siecles du moyen âge: Sicile et Provence orientale. In: Rencontres Internationales d'Archéologie et d'Historie d'Antibes (5th, 1984), L'Exploitation de la mer de l'antiquité a nos jours, Juans-Les-Pins, pp 107-114

Bresc H (1986) Un monde méditerranéen: Économie et société en Sicile 1300-1450. Ecole Française de Rome, Rome

Craig OE et al (2009) Stable isotopic evidence for diet at the imperial Roman coastal site of Velia (1st and 2nd centuries AD) in Southern Italy. Am J Phys Anthropol 139(4):572-583

Curtis RI (1991) Garum and salsamenta: production and commerce in materia medica. Brill, Leiden

Davidson JN (1997) Courtesans and fishcakes: the consuming passions of classical Athens. HarperCollins, London

\footnotetext{
40 Étienne (1970), Lagóstena Barrios (2014). Cfr., however, Lagóstena Barrios (2001, 380): the overall scant evidence for societates and fish salting in Hispania suggests partnerships had a small role.

41 These were language manuals of the imperial age and list Greek and corresponding Latin phrases for a range of common situations, such as going to the baths. Asking the price of fresh fish at the market warrants inclusion: Dickey (2012-2015, vol. 1), Colloquia Monacensia-Einsidlensia, 8 a-d.

42 Dickey (2012-2015, vol. II, 31), Colloquium Harleianum 21b-c.
} 
Dickey E (2012-2015) The colloquia of the Hermeneumata Pseudodositheana, vol 2. Cambridge UP, Cambridge

Djaoui D, Piquès G, Botte E (2014) Nouvelles données sur les pots dits "a garum” du Latium, d'après les découvertes subaquatiques du Rhône (Arles). In: Botte E, Leitch V (eds) Fish \& ships: production and commerce of salsamenta during Antiquity. Production et commerce des salsamenta durant l'Antiquité. Actes de l'atelier doctoral, Rome 18-22 juin 2012. Errance, Arles and Centre Camille Jullian, Aix-enProvence, pp 175-198

Étienne R (1970) A propos du «garum sociorum». Latomus 29(2):297-313

García Vargas E (2016) Littoral landscapes and embedded economies: tuna fisheries. In: Bekker-Nielsen T, Gertwagen R (eds) The inland seas: towards an ecohistory of the Mediterranean and the Black Sea. F. Steiner Verlag, Stuttgart, pp 255-286

Ghedini F, Novello M (2005) Mare realistico e mare mitologico nella produzione musiva dell'Africa Proconsolare: alcuni esempi. In: Giannatasio BM et al. (eds) Aequora, $\pi$ ó $\nu \tau o s$, jam, mare. Mare, uomini e merci nel Mediterraneo antico. Atti del Convegno Internazionale Genova, 2-10 Dicembre 2004. All'Insegna del Giglio, Borgo S. Lorenzo, pp 182-194

Højte JM (2005) Archaeological evidence for fish processing in the Black Sea region. In: Bekker-Nielsen T (ed) Ancient fishing and fish processing in the Black Sea region. Aarhus University Press, Aarhus, pp $133-160$

Horsley GHR (1989) A fishing cartel in first-century Ephesos. In: Horsley GHR (ed) New documents illustrating early christianity, vol 5. Ancient History Documentary Research Centre, Macquarie University, Marickville, pp 95-114

Lagóstena Barrios L (2001) La producción de salsas y conservas de pescado en la Hispania Romana (2 a.C.-6 d.C.). Edicions Universitat Barcelona, Barcelona

Lagóstena Barrios L (2014) Nuevas consideraciones sobre la societas cetariorvm gaditanorvm. In: Maestre JM et al (eds) Baetica renascens, vol I. Federación Andaluza de Estudios Clásicos, Cadiz and Malaga, pp 93-108

Lowe B (2016) The trade in fish sauce and related products in the western Mediterranean. In: Bekker-Nielse T, Gertwagen R (eds) The inland seas: towards an ecohistory of the Mediterranean and the Black Sea. F. Steiner Verlag, Stuttgart, pp 215-236

Lytle E (2006) Marine fisheries and the ancient Greek economy. Ph.D. Dissertation, Duke University

Lytle E (2010) Fish lists in the wilderness: the social and economic history of a Boiotian price decree. Hesperia 79:253-303

Marzano A (2013) Harvesting the sea: the exploitation of marine resources in the Roman mediterranean. Oxford UP, Oxford

Marzano A (2017) Classical archaeology and the ancient economy. In: Lichtenberg A, Raja A (eds) The diversity of classical archaeology. Brepols, Turnhout, pp 101-113

Mylona D (2008) Fish-eating in greece from the fifth century BC to the seventh century AD: a story of impoverished fishermen or luxurious fish banquets?. Archaeopress, Oxford

Novello M (2007) Scelte tematiche e committenza nelle abitazioni dell'Africa Proconsolare. F. Serra Editore, Pisa and Rome

Parma A (1995) Una nuova iscrizione di Misenum con un veterano duovir della città. Ostraka 4(2):301-306

Peurière Y (2003) La Pêche et les poissons dans la littérature latine: Des origines à la fine de la période augustéenne. Latomus, Brussels

Purcell N (1995) Eating fish: the paradoxes of seafood. In: Wilkins J, Harvey D, Dobson M (eds) Food in antiquity. University of Exeter Press, Exeter, pp 132-149

Rowan E (2014) The fish remains from the Cardo V sewer: new insights into consumption and the fishing economy of Herculaneum. In: Botte E, Leitch V (eds) Fish and ships. Production et commerce des salsamenta durant l'Antiquité. Errance, Arles and Centre Camille Jullian, Aix-en-Provence, pp 61-73

Sirks AJB (1991) Food for Rome: the legal structure of the transportation and processing of supplies for the imperial distributions in Rome and Constantinople. JC Gieben, Amsterdam

Vaccaro E, Capelli C, Ghisleni M (2017) Italic sigillata production and trade in rural central Italy: new data from the project 'excavating the Roman peasant'. In: de Haas TCA, Tol GW (eds) The economic integration of Roman Italy: rural communities in a globalizing world. Brill, Leiden, pp 231-262

Van der Veen M (2003) When is food a luxury? World Archaeol 34(3):405-427

Van Neer W, Ervynck A, Monsieur P (2010) Fish Bones and amphorae: evidence for the production and consumption of salted fish products outside the Mediterranean region. JRA 23:161-195 